\title{
Sincerely James: Reconsidering Frederick Francis's Proposed Health Wish Formula
}

Journal for the Study of the New Testament

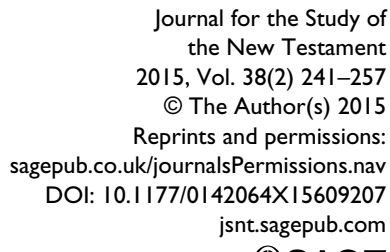

@SAGE

\section{Andrew M. Bowden}

Ludwig-Maximilians-Universität München, Germany

\begin{abstract}
This article interacts with Frederick Francis's well-known suggestion that Jas 5 contains a health wish formula. Based on more recent findings of epistolography, this article argues that the references to healing in Jas 5 contrast sharply with the first-century CE health wish formula(s). In addition to current research on Hellenistic epistolography, this article offers three further pieces of evidence which suggest that the letter of James does not conclude with a health wish formula, but rather with a promise of restoration from spiritual sickness.
\end{abstract}

\section{Keywords}

Epistle of James, epistolary conclusions, Frederick Francis, health wish formula, James 5.13-18

\section{Introduction}

Frederick Francis's article 'The Form and Function of the Opening and Closing Paragraphs of James and 1 John' (1970) is widely considered to be an influential and ground-breaking study related to the epistle of James. His essay is cited in most articles, monographs and commentaries on James - and rightly so, for he is credited with bringing serious attention to the epistolary structure and coherence of the letter. In doing so, he offered a convincing alternative to Dibelius's view (1976) - who emphasized the epistle's supposedly random, patchwork nature and highlighted key features of the opening and closing paragraphs of James.

Despite the numerous insights provided by his study, this article will argue that Francis's observations about the conclusion of James have been

\section{Corresponding author:}

Andrew M. Bowden, Ludwig-Maximilians-Universität München, Geschwister-Scholl-Platz I, 80539 Munich,

Germany.

Email: Andrew.Bowden@evtheol.uni-muenchen.de 
misunderstood and misused by many interpreters. I will firstly summarize Francis's viewpoints on the conclusion of James, especially as they relate to the presence of a health wish formula. ${ }^{1}$ Then, I will evaluate Francis's thesis against more recent studies on ancient epistolography. This will be followed by three pieces of evidence that point to Jas 5.13-18 as indicating a recovery from spiritual sickness. Such an analysis will ultimately help to clarify the issue of the presence or absence of a health wish formula in James and will illuminate the function of the conclusion within the overall context of the letter.

\section{Francis's Observations about the Health Wish in James 5}

Francis by no means offered a thorough investigation of epistolary conclusions or even, in particular, of the conclusion of the epistle of James. This is not surprising, given that a detailed analysis of James's health wish would have been impossible in a 16-page essay focusing on the introductions and conclusions of two NT epistles. In the course of his essay, Francis devotes eight pages to an analysis of the introduction to James, three pages to the body of the letter, twoand-a-half pages to $1 \mathrm{John}$, and one paragraph (composed of four sentences) to the possible oath and health formulas in Jas 5 (1970: 125). His thoughts on the health wish in James are as follows:

[Although Hellenistic letters can abruptly end without any closing formulas] one of the final phrases identified by Exler in his study of Hellenistic epistolography is $\pi \rho \dot{o} \pi \dot{\nu} \tau \tau \omega \nu$ with a health wish. Another class of closing formulas is the oath formula. One must ask: why do the topics, 'oaths' and 'the recipients' health' appear in James, and why precisely at the end, and why set off by $\pi \rho \dot{o} \pi \alpha \dot{\nu} \tau \omega \nu$ (especially after the eschatological teaching and thematic reprise)? It would seem that James 5.12-20 may be occasioned by epistolary forms providing for oath formulas and expression of concern for the recipients' health at the end of the letter.

Francis offers no further comment about the health wish. ${ }^{2}$ The brevity of his remarks should not be overlooked: he simply makes a passing reference to the

1. It is important from the outset to clarify the terms 'health wish' and 'health wish formula'. Authors generally use the phrases synonymously (e.g., White 1986: 202; Weima 1994: 35). Thus, 'health wish' refers to the common practice in Hellenistic letters of expressing concern for the health of the recipients in a formulaic manner. That this formula can simply be called a 'health wish' is confirmed by Weima, who states that 'the health wish was an established epistolary convention' (1994: 35).

2. Francis does, however, note several other features of Hellenistic epistolary conclusions that appear in Jas 5 (1970: 124-25). The first of these is eschatological instruction, and this is seen in James's reference to the imminent 'coming of the Lord' (5.7-9) (Francis compares this with 1 Cor. 16.22; 1 Thess. 5.23; 1 Pet. 5.1; 2 Pet. 3.12-14; Jude 18, 21). Secondly, Hellenistic 
health wish as it relates to his overall thesis. Furthermore, in his remarkably terse comment about the health wish, he defers to Exler's monograph in which the formula is discussed (1923: 114). Based in part on the letter's 'recognizable epistolary close' (1970: 126), he argues that the literary character of James must be reassessed and that the letter can be read as a coherent epistle 'from start to finish' (1970: 126).

Thus, it may safely be said that Francis's remarks about the supposed health wish formula in James were not the focus of his study. Quite the contrary, they were an afterthought. The importance of his essay was the suggestion that James should be read in a new way. Rather than being understood as a random collection of pithy sayings, James can be read as a genuine, coherent and purposeful epistle. In order to demonstrate this, Francis alludes to the possibility of a health wish in Jas 5. Due to the nature and purpose of Francis's discussion about epistolary features in the conclusion of James, it would be an error for scholars to accept uncritically his proposal regarding the health wish formula. His discussion is far too brief to be considered the final word on the presence of such a formula in the letter. Instead, his suggestion should be treated as a hypothesis that needs to be rigorously tested through comparisons with other health wishes in ancient Greek epistolary conclusions. Furthermore, studies on epistolography published since 1970 also need to be taken into account.

\section{The Health Wish Formula in Light of Recent Studies on Ancient Epistolography}

As previously noted, Francis cites Exler's theory about the function of $\pi \rho o ̀ ~ \pi \alpha ́ v \tau \omega \nu$ and a health wish in Hellenistic conclusions (1970: 125). Surprisingly, Francis did not submit Exler's theory to further investigation. This hypothesis, while important, has nevertheless been supplemented by more recent investigations of Hellenistic letters, ${ }^{3}$ which shed much light on the possibility of a health wish formula in James.

In his monograph on Hellenistic epistolary conclusions and their relevance for the interpretation of Paul's letters, Jeffrey Weima (1994: 35) warns that great caution should be used in identifying a health wish: 'It appears difficult

epistles often conclude with a thematic reprise, which might explain the admonition against strife in Jas 5.9 (Francis offers the examples of 1 Pet. 5; 2 Pet. 3; Jude 18ff.). Thirdly, relying solely on Exler, Francis explains Jas 5.12 in the light of oath and health formulas, as already noted. Finally, Francis suggests that prayer is a feature of NT epistolary conclusions (cf. 2 Cor. 9.14; 13.7; Eph. 6.18-19; Phil. 4.6; Col. 4.2-3; 1 Thess. 5.17; Phlm. 22; Heb. 13.18), which might explain Jas 5.16-18.

3. See, e.g., Doty 1973; Stowers 1986; White 1986; Weima 1994; Porter and Adams 2010; Weima 2010: 307-45. 
to discern a definitive pattern in a health wish. For not only does a health wish possess a bewildering array of variations in form, it also occurs in different locations: in the opening section, in the closing section, and frequently in both'. Weima then adds a comment that has a great bearing on the question of the presence or absence of a health wish in Jas 5: 'Although a Greek epistolary health wish exhibits a great deal of variety, it still possesses a relatively fixed basic form, depending on whether it is located at the opening or closing of the letter' (1994: 35). Significantly, the form of the closing health wish shows much less variety and flexibility than the opening health wish (Weima 1994: 37). When the health wish appeared in a letter's conclusion it had a relatively fixed form:

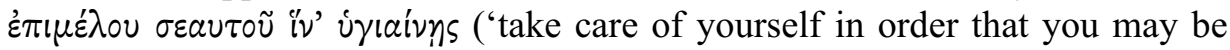
healthy'; cf., e.g., Papyrus Mert 62). ${ }^{4}$ This form had only slight, minor alterations, such as:
P. Petr. 2

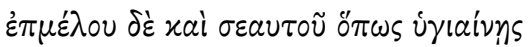
P. Oslo 47

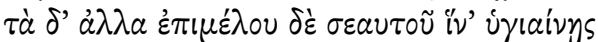
P. Oxy. 294

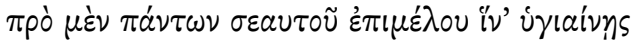
P. Lond. 42

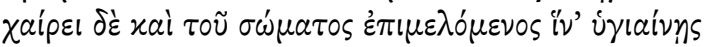
P. Yale 42

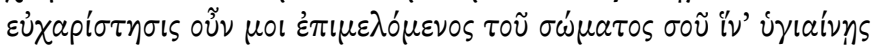

(Weima 1994: 37-38)

By the end of the first century CE, the closing health wish practically disappeared because it had been assimilated with the farewell wish है $\rho p \omega \sigma o$ or $\varepsilon \dot{v} \tau \cup \chi \varepsilon l$

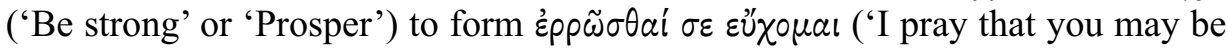
well') (Weima 1994: 37-38). ${ }^{5}$ This observation is corroborated by the earlier comments of Exler (1923: 114-20), who explains that since the farewell wish is almost identical in meaning to the health wish, the latter became superfluous as an epistolary convention (a point which is not mentioned in Francis's essay). These insights are confirmed by John L. White in his study on epistolography

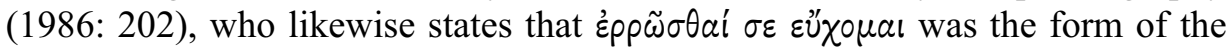
closing health wish from the middle of the first century CE to the third century $\mathrm{CE}$ (see the examples in note 5 below).

4. Exler makes this observation after depicting the health wishes of 55 papyri (1923: 113-15).

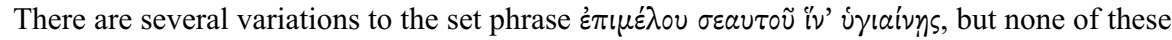

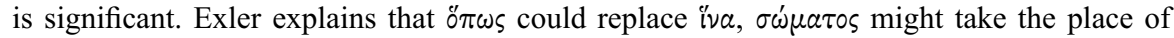

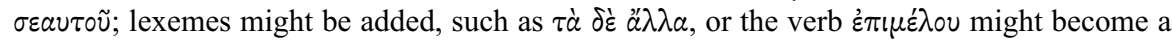

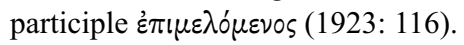

5. Unfortunately, Weima provides no specific examples of this expression. For these, see, e.g.,

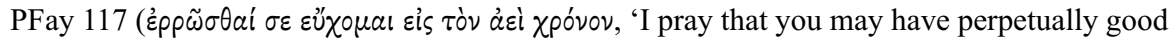

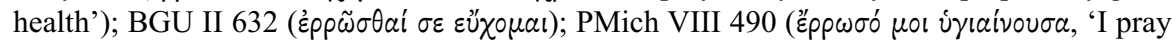
that you are healthy'). White 1986 provides numerous examples (e.g., PMert II 63; PMich VIII 464; BGU 632; PMich VIII 490; PMich VII 491; etc.). 
Thus, at the time when the epistle of James was written, Hellenistic epistles that employed a closing health wish used the formulaic phrase 'I pray that you may be well'. This health wish is only found in some Hellenistic epistles and only occasionally in their conclusions. ${ }^{6}$ Significantly - but without seeking to address the question of authorship - it should be noted that in the letter sent by the Jerusalem Council according to Acts 15 (in which James had a significant role), it is $\varepsilon^{\prime} \rho \rho \omega \sigma \theta \varepsilon$ that appears as the farewell wish (15.29).

These insights shed valuable light on the presence - or absence - of a health wish formula in the conclusion to James. Contrary to Exler and Francis, $\pi \rho o ́ ~ \pi \alpha ́ \nu \tau \omega \nu$ appears in Jas 5.12 in a command against oaths, not with reference to health. Moreover, scholars who study Hellenistic epistles warn about the dangers of comparing the forms in NT epistles with those found in papyri, since 'with few exceptions, Christian letters are considerably longer than ordinary Greek letters' (White 1986: 19). Additionally, the typical word used in the health wish formula (before it was fused with the farewell wish) was i $\gamma ı$ i $v \omega$. However, this word is absent from Jas 5, and the healing is described rather with the words

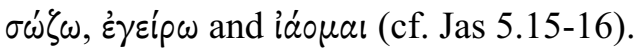

In light of these observations, Francis's identification of a closing health wish formula in Jas 5 must be called into question. James's instruction in 5.13-18 can hardly be associated with the fixed pattern of the typical formula that was in use during the first century CE. And, even if Francis is correct about a health wish being used to signal the conclusion of James, the possibility remains that the author could modify the custom by formulating a health wish that suits his or her own purposes (for example, by wishing the readers spiritual rather than physical health). Paul, after all, is known for doing precisely that in the introductions to his letters. ${ }^{7}$ Thielman (2010: 31$)$ notes that such a practice was not uncommon: Greek writers, especially philosophers, often changed the standard epistolary greeting in order to make some point consistent with their convictions. Thus, commenting on Paul's creative deviations, Thielman states that Paul employs these creative changes to 'alert his readers to the theological significance of the letter' (2010: 31). Perhaps, then, the conclusion of James has been constructed in a way that restates a theological theme of the letter. This point will be examined in more detail at a later point in this article.

6. The primary sources from which examples can be drawn exceed the scope of this article. A helpful discussion on this point can be found in White's monograph: 'In an earlier, random sampling of 660 letters [!] from Graeco-Roman Egypt, I found that about one in six letters had the wish (prayer) for health in the letter opening' (1986: 200). He explains that legal documents and petitions or applications omit the health wish, while familiar letters express it more often.

7. Notable examples include Rom. 1.1-7; 1 Cor. 1.1-9; Gal. 1.1-9; Phil. 1.1-6. The unique features of these Pauline introductions are discussed by Tite (2010: 57-99). 
Some aspects of Francis's thesis have indeed been met with criticism by scholars. ${ }^{8}$ However, his remarks regarding the health wish in James remain surprisingly unquestioned. ${ }^{9}$ In light of the factors mentioned above, it may be said that the presence of a health wish formula in Jas 5 is very doubtful. If a health wish is present, it is certainly outside the mould of the fixed, established customs of the day. In this case, if 5.13-18 is to be interpreted as a health wish, it can hardly be called a health wish formula, since the author has constructed a paragraph related to healing that is unprecedented in comparison to Hellenistic epistles.

\section{Additional Evidence against the Traditional Health Wish in James}

Up to this point we have compared Francis's theory about a health wish in James with more recent findings of epistolography. We shall now consider three additional arguments that bring into question the classification of Jas 5.13-18 as a traditional health wish. These three pieces of evidence prompt us to interpret the sickness and healing described in Jas 5.13-18 as being spiritual, rather than physical, in nature. ${ }^{10}$

8. According to T. Cargal (1993: 214), for example, 'It must be noted that with regard to several of these closing conventions James does not directly employ them so much as play on them'. Hartin (1991: 27) faults Francis's insistence on noting close similarities between the introductory and concluding paragraphs. Francis is also critiqued by Wuellner (1978: 34), and also by Kümmel (1973: 408 nn.15, 17) who dismisses Francis's proposal without discussion.

9. It is surprising that scholars who refer to Francis's position do not offer their own first-hand investigation into the nature of the health wish formula, or even refer to literature on the topic. Two examples demonstrate this point. First, Ralph Martin (1988: 186-221) bases his discussion of the conclusion of James on Francis's thesis, thereby assuming the presence of a traditional health wish. Martin explains that there are 'substantial' and 'well grounded' reasons for understanding Jas 5.7-20 as containing epistolary features, including a health wish formula (1988: 186). The second example comes from Peter Davids's respected commentary on James (1982). Again, citing Francis, Davids states: 'The second, third, and fourth [paragraphs of the conclusion] are dictated by the epistolary form and thus speak respectively of oaths, a health wish, and the purpose for writing, all of which one would expect in the literary epistle ...' (1982: 181). Later, in his discussion of Jas 5.13-18, and again relying exclusively on Francis, Davids continues: '[H]ealth wishes were customary in the endings of epistles ...' (1982: 191). These two examples are representative of the way 5.13-18 is often approached. A brief observation by Francis has been readily accepted when dealing with the conclusion of James.

10. For a comprehensive summary of various theories on Jas 5.13-18, see my article 'An Overview of the Interpretive Approaches to James 5:13-18' (2014a). Those who view the sickness as physical in nature include von Soden 1893: 201-202; Plummer 1899: 323-49; Ropes 1916; Pickar 1945: 170; Windisch 1951; Reicke 1964; Wilkinson 1971: 326-45; Adamson 1976; Mußner 1981: esp. 216-30; Davids 1982; Martin 1988; Shogren 1989; Mayor 1990: 483-84; Jeffrey 1993: 59; Johnson 1995; Collins 1997; Moo 2000; Popkes 2001; Kaiser 2006; and McKnight 2011. 
There are a handful of scholars who suggest that Jas 5 speaks of restoration from spiritual sickness. ${ }^{11}$ These authors generally point out that James's terms for sickness and healing can have physical or spiritual overtones depending on the context. According to this view, $\dot{\alpha} \sigma \theta \varepsilon \nu \varepsilon \dot{\omega} \omega$ (5.14) should be translated based on its usage in other NT epistles where it refers to weakness in faith or weakness in conscience, rather than its Synoptic meaning of physical sickness. ${ }^{12}$ Similarly, since healing is described in Jas 5.16 with the term iáoual, it implies spiritual healing (cf. also Mt. 13.15; Heb. 12.13; 1 Pet. 2.24). Those who interpret the sickness as spiritual in nature regard 'anointing with oil' in 5.15 as a reference to refreshment and grooming. ${ }^{13}$ Finally, the instructions offered in these verses simply do not work in bringing about a guaranteed physical healing.

Building on these arguments for interpreting Jas 5.13-18 as denoting spiritual rather than physical healing, I shall advance three relatively unexplored arguments that indicate the absence of a health wish formula in Jas 5.14 These three aspects, all of which point to a recovery from spiritual sickness being expressed in the conclusion to James, include (1) the interpretation provided by the earliest commentators on Jas 5 (i.e., the early reception history of these verses), (2) the

11. Those who argue in favour of this position include Lange 1867; Meinertz 1932: 23-36; Armerding 1938: 195-201; Friesenhahn 1938: 185-90; and Blue 1983: 834-35. Hayden (1981: 258-65) takes a unique approach by stressing the use of the word $x a ́ \mu \nu \omega$ in Jas 5.15. He explains, "To be "weary" in the spiritual battle is the sense of $x \alpha \dot{\alpha} \mu \nu \omega$, and James says "the prayer offered in faith will restore the one who is weary".' Howard (2001: 260-63) similarly argues for interpreting the sickness as a mental state, perhaps even depression, since in con-

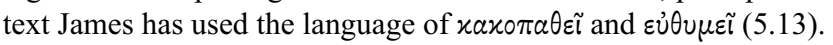

12. The term is generally used in the gospels for illness or bodily weakness (but see Mt. $26.41=$ Mk 14.38). Its occurrences are usually found (1) in summary reports of Jesus' ministry (cf. Jn 2.23 ; 6.14), (2) in commission accounts (Mt. 10.8; Lk. 9.2; 10.9) and (3) in accounts of specific healings (cf. Jn 4.46-54). For Paul, the term can carry physical or moral implications, depending on the context. The classic example where the term denotes psychological weakness is

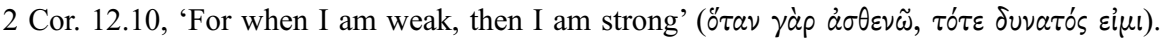
For Paul's use of the term, see Black 2012.

13. There are numerous explanations of James's reference to oil. Wall (1997: 265) categorizes these into three main groups: (1) oil is purely medicinal, (2) it is religious/cultic, (3) it is a metaphor for divine blessing. Popkes (2001: 343) argues that this threefold categorization fails to account for the various usages of oil. He notes the connection between anointing and exorcism, medicinal therapy, as a symbol of wellbeing, a religious-cultic act (such as for OT offerings), preparation of the dead, a symbol of blessing, of consecration for priests and kings, and a symbol of the Holy Spirit (Isa. 10.1; 60.1; Exod. 29.7). Another lengthy discussion of the reference to oil in James can be found in Moo 2000: 137.

14. I have advanced a fourth argument in my article 'Translating $\alpha \dot{\sigma} \theta \varepsilon v \varepsilon$ ' $\omega$ in James 5 in Light of the Prophetic LXX' (2014b). In this article I draw attention to the epistle's numerous allusions to the OT prophetic literature (LXX). Significantly, the term $\dot{\alpha} \sigma \varepsilon v \varepsilon \dot{\varepsilon} \omega$ is used prominently in the prophetic texts in connection with Israel's spiritual sickness, making it plausible that James had this context in mind in ch. 5 . 
similarities between the conclusions of James and 1 Peter, and (3) Jas 5.13-18 in light of the context and argument of the letter.

\section{I. Origen and Chrysostom on Sickness in James 5}

The early church is silent about any sort of ritual for healing the sick as described in James. Rather, there is a curious reluctance during the first three centuries to connect Jas 5 with physical healing: 'To the end of the patristic period there is no actual rite or form known to us which gathers the presbyters round the bed of the sick and provides a text for their use' (Halliburton 1993: 89). Indeed, when the 16 provincial synods gathered in the ninth century $\mathrm{CE}$ to recommend the sacrament of anointing with oil, only 3 of the 16 synods referred to the text of Jas 5.14. Thus, even as late as $800 \mathrm{CE}$, Jas 5.13-18 was not understood as a clear reference to the anointing of the physically sick (Friesenhahn 1938: 189-90).

The oldest available references to these verses are found in Origen and Chrysostom, who interpret the sickness in Jas 5 as spiritual in nature. In his second homily on Leviticus, Origen in fact quotes Jas 5.14-15 to describe spiritual healing (Hom. Lev. 2). Commenting on Lev. 4 - a passage instructing Israel about the various sacrifices to be offered by priests, by the congregation of Israel and by individuals - Origen concludes that these sacrifices correspond to seven types of sacrifices that Christians can offer for the remission of sins. Such sacrifices include baptism, martyrdom, alms, forgiveness, the conversion of wandering sinners (Jas 5.20), abundance of love, and penance. It is in his explanation of the seventh sacrifice - penance - that Origen quotes Jas 5.14-15. He describes this penance as a period of solemn grieving, when many tears are shed and the sinner is so distraught over iniquity that 'he is not ashamed to make known his sin to the priest of the Lord and to seek a cure' (Hom. Lev. 2.4.5). ${ }^{15}$ The penitent one should pray the words of Ps. 31.5, a psalm in which the contrite are forgiven after confessing their injustice to the Lord. According to Origen, such penance fulfils the instructions of Jas 5.14: it is an offering made by a soul 'under the burden of sin', which is accompanied by bitter weeping and by fasting (abstinentia) (Hom. Lev. 2.4.5).

James 5.14 is also mentioned by John Chrysostom, who applies it to a discussion of Christian priests and the honour they should be given. Priests are to be more respected than parents who birthed children to physical life, since, according to Chrysostom, priests 'birth' believers through baptism to the true life of grace (Sac. 3.6). And unlike Jewish priests who received honour even though their work included mundane tasks such as examining lepers, Christian priests deal not with bodily leprosy, but with the spiritual cleansing of the soul.

15. Translation from Barkley 1990: 47. The critical edition can be found in Borret 1981. 
Chrysostom writes that priests have often used their authority to forgive sins

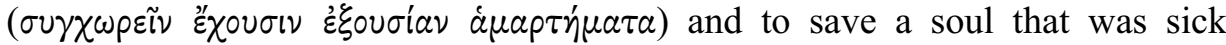

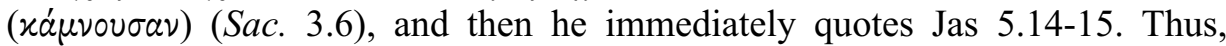
Chrysostom interprets this passage as applying to a context of soul-sickness and the forgiveness of sins.

Therefore, Origen and Chrysostom - two of the earliest Christians to comment on Jas 5.13-18 - applied the passage to spiritual sickness, which causes us to question further Francis's thesis about a traditional health wish in Jas 5.13-18.

\subsection{Parallels between James 5.I3-I8 and I Peter 5.I-I 4}

An analysis of the presence or absence of a health wish in James should also consider the conclusion of 1 Peter. As is commonly recognized, there is a striking

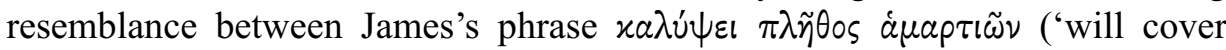

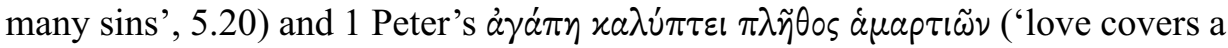
multitude of sins', 4.8). ${ }^{16}$ Beyond this echo, the conclusions of both epistles share other significant parallels:

\begin{tabular}{|c|c|}
\hline I Peter 5 & James 5 \\
\hline v. I $\pi \rho \varepsilon \sigma \beta u \tau \varepsilon ́ \rho \circ u \varsigma$ & v. $14 \pi \rho \varepsilon \sigma \beta u \tau \varepsilon ́ \rho \circ u \varsigma$ \\
\hline v. 6 ư $\psi \dot{\omega} \sigma n$ & 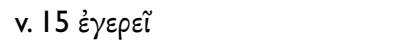 \\
\hline 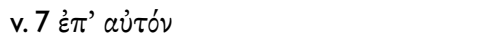 & 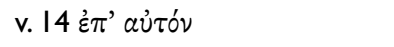 \\
\hline v. $9 \sigma \tau \varepsilon p \varepsilon \circ \grave{i} \tau \tilde{\eta} \pi i ́ \sigma \tau \varepsilon l$ & v. $15 \dot{\eta} \varepsilon \dot{\chi} \chi \dot{\eta} \tau \tilde{\eta} \varsigma \pi i ́ \sigma \tau \varepsilon \omega \varsigma$ \\
\hline 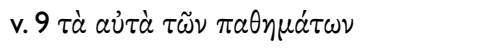 & 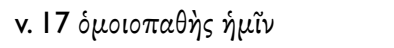 \\
\hline 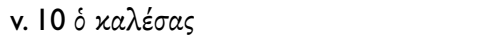 & v. $14 \pi \rho \circ \sigma \varkappa \alpha \lambda \varepsilon \sigma \alpha ́ \sigma \theta \omega$ \\
\hline v. $10 \sigma \theta \varepsilon \nu \omega ́ \sigma \varepsilon l$ & v. $14 \dot{\alpha} \sigma \theta \varepsilon \nu \varepsilon \tilde{\imath}$ \\
\hline 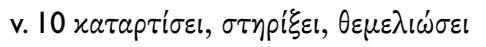 & v. $15 \sigma \dot{\omega} \sigma \varepsilon l, \dot{\varepsilon} \gamma \varepsilon \rho \varepsilon \tilde{\iota}, \dot{a} \phi \varepsilon \theta \dot{\eta} \sigma \varepsilon \tau \alpha \iota$ \\
\hline
\end{tabular}

Of course, there are also differences between their conclusions. For example, 1 Peter comports much more closely with the typical epistolary conclusion, since the letter contains a doxology (5.11), farewell greetings (5.13) and a postscript (5.14). The themes and focus of Peter's conclusion also differ from James's. 1 Peter 5.1-10 specifically address the elders and younger members of the community (notice that these groups are addressed in the vocative). The elders are instructed to follow Christ, the chief shepherd (v. 4), by leading through example. In return, younger members of the community should submit to the leaders (v. 5), knowing that God will raise them in the proper time (v. 6). Despite their

16. A nuanced discussion of the overlap between these and other passages in James and 1 Peter can be found in Allison 2013: 67-70. 
worries and their fierce enemy (vv. 7-8), the audience can trust in their eternally gracious God (v. 10a), who will confirm, strengthen and establish them (v. 10b) in the face of their trials. In contrast to 1 Peter, the conclusion of James addresses those who may be $\alpha \sigma \theta \varepsilon \nu \varepsilon \tilde{\imath}$ (5.14); the elders are not the main focus.

The themes vary in both conclusions as well. James, as we shall note in the next section, focuses on his audiences' need for repentance, while the author of 1 Peter focuses on the physical trials of his audience. This distinction can be observed by noting how often Peter makes use of the term $\pi \dot{\alpha} \sigma \chi \omega^{17}$ (e.g., 2.19, $20,21,23 ; 3.14,17,18 ; 4.1,13,15,19 ; 5.1,9)$, while it is absent from James. ${ }^{18}$ In light of this difference, Konradt explains that Peter's 'focus is on the theme of suffering, [which is] central to Peter as a whole ... This is different in James' (2009: 104). ${ }^{19}$

What bearing do these observations have on the question of a health wish in James? While recognizing the differences between them, 1 Peter provides a point of comparison for James's conclusion due to lexemic and syntactic overlap. ${ }^{20}$ Despite 1 Peter's focus on the audience's physical suffering, it concludes without a health wish. The conclusion centres on issues related to leadership, submission and the Christians' spiritual foe. This lends credibility to the theory that a wish for physical health is by no means a necessity in the closing section of a NT epistle. James was certainly not alone in omitting the traditional health wish formula.

\subsection{The Conclusion of James in Light of the Context and Argument of the Letter}

As with any ancient text, Jas 5.13-18 must be interpreted in light of its literary context in the letter. The fact that these verses function as the letter's conclusion has sometimes puzzled interpreters, who occasionally find themselves at a loss to explain how a conclusion dealing with physical healing fits in an epistle that otherwise focuses on spiritual matters. McKnight's sentiments illustrate the problem: 'These verses demonstrate that James closes this letter with random themes. Nothing central to 5.13-18 has emerged earlier in the letter' (2011: 431).

17. Louw and Nida define the term as follows: 'to undergo an experience, usually difficult, and normally with the implication of physical or psychological suffering - to experience, to suffer' (1996: 806, emphasis added).

18. I have devoted more attention to this point and to the relationship between James and 1 Peter in Bowden 2014c.

19. I have opted to translate this text rather than cite the original German.

20. Allison (2013: 67-68) lists twelve 'obvious and impressive [lexemic] parallels shared between the two letters'. On the similarities between James and 1 Peter, see Mayor 1990: 120-25 and Konradt 2009: 101-10. Konradt speculates that the similarities in language occurred because of intersecting traditions in Antioch (2009: 117). 
Such a viewpoint is brought into question, however, if - contrary to Francis's proposal - James concludes with instruction about spiritual sickness.

If James were to conclude with a reference to physical healing, the letter could certainly be accused of ending with a random and disconnected theme, which in fact some authors have alleged: '[T] he sudden emergence of instruction dealing with a ministry of divine healing for the sick at the end of a book stressing solely matters of spiritual concern seems somewhat incongruous' (Hayden 1981: 259). However, a conclusion that discusses restoration from spiritual sickness fits seamlessly in the overall scheme of the letter, ${ }^{21}$ and, in this respect, takes into account the function of ancient epistolary conclusions, which aimed to recapture the whole writing and to finalize the motifs. ${ }^{22}$ Since conclusions functioned as a hermeneutical spotlight to (re)affirm the central concerns of the letter, they were anything but haphazard or random. Rather, 'epistolary closings are to be seen as intimately related to the concerns addressed in the bodies of their respective letters' (Weima 1994: 22). Weima points out that just as introductory thanksgivings foreshadow major topics in letters, conclusions serve to 'highlight and encapsulate' the main points previously taken up in the body; they work like introductions, but in reverse (1994: 22). Thus, one should expect to encounter the primary themes of the discourse in an epistle's conclusion; it offers the final opportunity for the audience to change or modify its thinking and attitude, and it provides a recapitulation of the argument.

Given these arguments about the intended role of Hellenistic epistolary conclusions, it is unlikely that James would conclude with a disconnected health wish. If, however, the letter ends with a promise of spiritual restoration, it summarizes a major theme of the letter. The theme of repentance from sin is prominent throughout the discourse, as I shall now briefly illustrate.

The related concepts of temptation, sin and repentance occur in the first verses of James and continue throughout the epistle. Several scholars interpret the term 'diaspora' in 1.1 as an early hint by the author that certain sins need to be confronted and met with sorrowful repentance (see, e.g., van Unnik 1993: 84; Bauckham 1999: 14; Verseput 2000: 99-100; Jackson-McCabe 2003: 714; Wachob 2007: 159). ${ }^{23}$ The epistle's introduction also mentions temptation (1.13), the origin of $\sin (1.13-18)$ and an abundance of wickedness in the lives of the

21. Elsewhere I have examined the argument and flow of the letter; see Bowden 2013: 3-20.

22. See, for example, Black 1995: 23, Frankemölle 1990: 170, 183, Francis 1970: 124. Examples include 1 Jn 5.18-20.

23. According to Bauckham, diaspora implied more than simply 'exile'; it alluded to the scattering of God's people as punishment for their sins (1999: 14). Similarly, Verseput explains that the Jewish Diaspora was widely perceived as 'evidence of divine displeasure from which only national repentance and divine mercy could bring relief' (2000: 100). For further explanation about the connection between diaspora and sin, see the authors cited above. 
readers (1.21). Chapter 2 focuses on the audience's sin of favouritism (2.9) and provides a definition of $\sin (2.8-11)$. Then the tongue is identified as the world of iniquity causing all believers to stumble (3.1-3), before the readers are chastised for desiring and envying, murdering and waging war, and, after not getting what they want, they finally turn to God in prayer (4.1-3). Rather than designating the audience as 'brothers', James calls them 'sinners', 'double minded' and 'adulteresses' (cf. Jobes 2009: 139). After defining $\sin$ in 4.17 as the failure to put one's faith into action, the epistle closes with a call to turn sinners from their wandering (5.20). The final words about forgiveness and $\sin (5.16-20)$ bring the epistle to a logical, coherent end, since these themes have been prominent from the very beginning of the letter (Bowden 2014c: 121-22). Closely related to the theme of sin is the recurring theme of judgment (e.g., 2.12-13; 3.1; 4.11; 5.9, 12).

Numerous scholars have emphasized the prominence of sin throughout the letter of James. Thurén (1995: 282), for example, identifies the motif's prominence (particularly in chs. 2-4), explaining the author's wish 'to demonstrate what imperfection and inconsistency mean in practice'. Ironically, McKnight - who, as we noted, considers the epistle's conclusion to be disconnected - nevertheless identifies the recurring themes of sin and repentance in James. He draws attention to the community's impulsive language (2011: 162), their 'verbal sins' (p. 274), their 'divisive and sinful' actions (p. 188) and their hubris and idolatry (p. 366). He explains that the 'power of sin' has been 'unleashed' so that the community as a whole has the status of transgressors (p. 210). In light of their blatant sins, McKnight then emphasizes the theme of repentance: 'breaking the Torah ought to lead the messianic community back to their knees and generate a repentance that leads to a life lived in obedience' (p. 173). Accordingly, James wants to 'shame them into reform' (p. 176) and 'to teach people to repent' (p. 342). McKnight sees repentance as the entire theme of 4.7-9 (p. 357). His identification of these themes makes his treatment of James's conclusion (namely, his blank dismissal of recovery from spiritual sickness) all the more incongruous.

We are not alone, then, in emphasizing the concepts of sin and repentance in James. That these concepts also appear in 5.13-18 should therefore come as little surprise. Since the author has repeatedly demonstrated the audience's need to

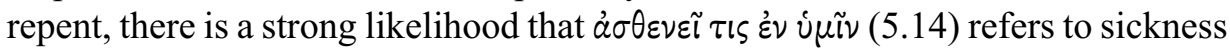
that is spiritual in nature. By concluding with a promise of restoration to spiritually sick believers, 5.13-18 recapitulates the argument and themes of the epistle and thereby effectively accomplishes the purpose of a Hellenistic conclusion. ${ }^{24}$ By proclaiming a message of spiritual restoration, James's conclusion fits seamlessly in a letter that calls sinners to repentance.

24. Sigurd Kaiser's recent monograph (2006) on this passage does not discuss the role of 5.13-18 as an epistolary conclusion. 


\section{Conclusion}

This article has argued that Francis's thesis about the health wish formula is neither thorough nor proven, and that it should be carefully considered in the light of more recent discoveries in the study of epistolography. Once such an investigation is carried out, it becomes apparent that the references to sickness and health in Jas 5 are of a very different nature from the fixed health wish formula in circulation during the first century CE. The common health wish 'I pray that you may be well' hardly compares to James's lengthy discussion of prayer, forgiveness, the confession of sins and the anointing with oil (5.13-18). I have introduced three additional arguments which indicate that, rather than incorporating a health wish formula, James promises recovery from spiritual sickness: (1) Early reception history demonstrates that ancient Christian communities interpreted the sickness in 5.13-18 as spiritual in nature. Only much later was the passage associated with anointing the physically sick. (2) The conclusions of James and 1 Peter mirror each other in significant ways by offering promises that are spiritual rather than physical in nature. (3) By closing with a promise of spiritual restoration, Jas 5.13-18 recapitulates a major theme of the letter, namely repentance from sin. These factors imply that Francis's thesis about the presence of a health wish in James is highly suspect. When recent discoveries from the field of epistolography are fully taken into account, there is little that resembles the Hellenistic health wish formula in the conclusion to the letter of James. Rather, by offering hope to the spiritually repentant, 5.13-18 functions as a cohesive and sound conclusion to a letter focusing on spiritual matters.

\section{References}

Adamson, James

1976 The Epistle of James (NICNT; Grand Rapids, MI: Eerdmans).

Allison, Dale C., Jr

2013 James: A Critical and Exegetical Commentary (ICC; London: T\&T Clark).

Armerding, Carl

1938 “'Is Any among you Afflicted”: A Study of James 5.13-20’, BSac 95: 195-201.

Barkley, Gary Wayne

1990 'Homily 2 on Leviticus', in Origen: Homilies on Leviticus: 1-16 (trans. G.W. Barkley; Washington, DC: Catholic University of America Press): 39-51.

Bauckham, Richard

1999 James: Wisdom of James, Disciple of Jesus the Sage (New Testament Readings; New York: Routledge).

Black, David A.

1995 'The Discourse Structure of Philippians: A Study in Textlinguistics', NovT 37: $16-49$ 
2012 Paul, Apostle of Weakness: Astheneia and its Cognates in the Pauline Literature (rev. edn; Eugene, OR: Pickwick Publications).

Blue, J. Ronald

1983 'James', in J. Walvoord et al. (eds.), The Bible Knowledge Commentary (Wheaton, IL: Victor Books): 815-36.

Borret, M.

1981 Origène: Homélies sur le Lévitique (2 vols.; Sources chrétiennes; Paris: Éditions du Cerf).

Bowden, Andrew M.

2013 'The Fruit of Righteousness in James: A Study in Discourse Analysis', FNeo 26: 3-20.

2014a 'An Overview of the Interpretive Approaches to James 5.13-18', CBR 13.1: 67-81.

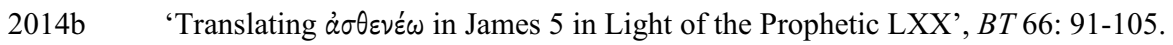

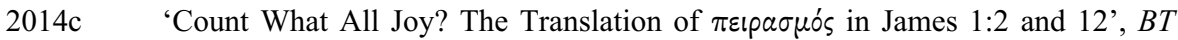
65.2: 113-24.

Cargal, Timothy B.

1993 Restoring the Diaspora: Discursive Structure and Purpose in the Epistle of James (SBLDS, 144; Atlanta: Scholars Press).

Collins, C. John

1997 'James 5.14-16a: What is the Anointing for?', Presbyterion 23: 79-91.

Davids, Peter H.

1982 The Epistle of James: A Commentary on the Greek Text (NIGTC; Grand Rapids, MI: Eerdmans).

Dibelius, Martin

1976 Commentary on the Epistle of James (Philadelphia: Fortress Press).

Doty, William G.

1973 Letters in Primitive Christianity (Philadelphia: Fortress Press).

Exler, Francis Xavier J.

1923 The Form of the Ancient Greek Letter: A Study in Greek Epistolography (Washington, DC: Catholic University of America).

Francis, Frederick O.

1970 'The Form and Function of the Opening and Closing Paragraphs of James and 1 John', ZNW 61: 110-26.

Frankemölle, Hubert

1990 'Das semantische Netz des Jakobusbriefes: Zur Einheit eines umstrittenen Briefes', BZ 34: 161-97.

Friesenhahn, Hans

1938 'Zur Geschichte der Überlieferung und Exegese des Textes bei Jak V, 14f.', BZ 24: $185-90$.

Halliburton, John

1993 'Anointing in the Early Church', in M. Dudley and G. Rowell (eds.), The Oil of Gladness: Anointing in the Christian Tradition (Collegeville, MN: SPCK): 77-91. 
Hartin, Patrick J.

$1991 \quad J a m e s$ and the Q Sayings of Jesus (JSNTSup, 47; Sheffield: JSOT Press).

Hayden, Daniel

1981 'Calling the Elders to Pray', BSac 138: 258-65.

Howard, J. Keir

2001 Disease and Healing in the New Testament: An Analysis and Interpretation (Lanham, MD: University Press of America).

Jackson-McCabe, Matt

2003 'The Messiah Jesus in the Mythic World of James', JBL 122: 701-30.

Jeffrey, John

1993 'Anointing in the New Testament', in M. Dudley and G. Rowell (eds.), The Oil of Gladness: Anointing in the Christian Tradition (Collegeville, MN: Liturgical Press): 46-76.

Jobes, Karen

2009 'The Minor Prophets in James, 1 \& 2 Peter and Jude', in M.J.J. Menken and Steve Moyise (eds.), The Minor Prophets in the New Testament (LNTS, 377; Edinburgh: T\&T Clark): 135-53.

Johnson, Luke T.

1995 The Letter of James: A New Translation with Introduction and Commentary (AB, 37A; New York: Doubleday).

Kaiser, Sigurd

2006 Krankenheilung: Untersuchungen zu Form, Sprache, traditionsgeschichtlichem Hintergrund und Aussage von Jak 5, 13-18 (WMANT, 112; Neukirchen-Vluyn: Neukirchener Verlag).

Konradt, Matthias

2009 'The Historical Context of the Letter of James in Light of its Traditio-Historical Relations with First Peter', in K.-W. Niebuhr and R.W. Wall (eds.), The Catholic Epistles and Apostolic Tradition (Waco, TX: Baylor University Press): 101-25.

Kümmel, Werner Georg

1973 Introduction to the New Testament (Nashville: Abingdon Press).

Lange, Johann Peter

1867 The Epistle General of James (trans. J. Mombert; New York: Charles Scribner).

Louw, Johannes P. and E.A. Nida (eds.)

1996 Greek-English Lexicon of the New Testament: Based on Semantic Domains (2 vols.; electronic edn; New York: United Bible Societies).

Martin, Ralph P.

1988 James (WBC, 48; Waco, TX: Word).

Mayor, Joseph B.

1990 The Epistle of James (Grand Rapids, MI: Kregel).

McKnight, Scot

2011 The Letter of James (NICNT; Grand Rapids, MI: Eerdmans). 
Meinertz, Max

1932 'Die Krankensalbung Jak 5.14f.', BZ 20: 23-36.

Moo, Douglas J.

2000 The Letter of James (PNTC; ed. D.A. Carson; Grand Rapids, MI: Eerdmans).

Mußner, Franz

1981 Der Jakobusbrief (4th edn; Freiberg: Herder).

Pickar, Charles

1945 'Is anyone Sick among You?', $C B Q 7$ : 165-74.

Plummer, Alfred

1899 The General Epistles of St. James and St. Jude (New York: Hodder \& Stoughton).

Popkes, Wiard

2001 Der Brief des Jakobus (THKNT; Leipzig: Evangelische Verlagsanstalt).

Porter, Stanley E. and Sean A. Adams (eds.)

2010 Paul and the Ancient Letter Form (Pauline Studies, 6; Leiden: Brill).

Reicke, Bo

1964 The Epistles of James, Peter, and Jude (AB, 37; New York: Doubleday).

Ropes, James Hardy

1916 A Critical and Exegetical Commentary on the Epistle of St. James (ICC; New York: Charles Scribner's Sons).

Shogren, Gary S.

1989 'Will God Heal Us? A Re-examination of James 5.14-16a', EvQ 61: 99-108.

Soden, Hermann von

1893 Die Briefe an die Kolosser, Epheser, Philemon, die Pastoral Briefe, der Hebräerbrief, die Briefe des Petrus, Jakobus, Judas (vol. 3; HKNT; Freiburg: Mohr Siebeck).

Stowers, Stanley K.

1986 Letter Writing in Greco-Roman Antiquity (LEC, 5; Philadelphia: Westminster Press).

Thielman, Frank

2010 Ephesians (BECNT; Grand Rapids, MI: Baker).

Thurén, Lauri

1995 'Risky Rhetoric in James?', NovT 37: 262-84.

Tite, Philip L.

2010 'How to Begin, and Why? Diverse Functions of the Pauline Prescript within a Greco-Roman Context', in Stanley E. Porter and Sean A. Adams (eds.), Paul and the Ancient Letter Form (Pauline Studies, 6; Leiden: Brill): 57-99.

Unnik, Willelm Cornelius van

1993 Das Selbstverständnis der jüdischen Diaspora in der hellenistisch-römischen Zeit (Leiden: Brill). 
Verseput, Donald J.

2000 'Genre and Story: The Community Setting of the Epistle of James', $C B Q 62$ : 96-110.

Wachob, Wesely Hiram

2007 'The Languages of "Household" and "Kingdom" in the Letter of James: A SocioRhetorical Study', in Robert L. Webb and John S. Kloppenborg (eds.), Reading James with New Eyes: Methodological Reassessments of the Letter of James (LNTS, 342; New York: T\&T Clark): 151-68.

Wall, Robert W.

1997 Community of the Wise: The Letter of James (Valley Forge, PA: Trinity Press International).

Weima, Jeffrey. A.D.

$1994 \quad$ Neglected Endings: The Significance of the Pauline Letter Closings (JSNTSup, 101; Sheffield: JSOT Press).

2010 'Sincerely Paul: The Significance of the Pauline Letter Closings', in S.E Porter and S.A. Adams (eds.), Paul and the Ancient Letter Form (Pauline Studies, 6; Leiden: Brill): 307-45.

White, John L.

1986 Light from Ancient Letters (Philadelphia: Fortress Press).

Wilkinson, John

1971 'Healing in the Epistle of James', SJT 24: 326-45.

Windisch, Hans

1951 Die katholischen Briefe (HKNT, 15; Tübingen: Mohr Siebeck).

Wuellner, Wilhelm H.

1978 'Der Jakobusbrief im Licht der Rhetorik und Textpragmatik', LB 43: 5-66. 